\title{
MOTIVASI BELAJAR TERHADAP HASIL BELAJAR MAHASISWA PADA PEMBELAJARAN DARING SAAT PANDEMI COVID-19
}

\section{Learning Motivation On Student Achievement Results In Online Learning During The Covid-19 Pandemic}

\author{
Asmawiyah Asmawiyah \\ Email: asmawiyah49@gmail.com \\ Program Studi Manajemen, Sekolah Tinggi Ilmu Ekonomi Tri Dharma Nusantara \\ Jalan Kumala 2 No.51 \\ Afiah Mukhtar \\ Email: afiah.muhtar@gmail.com \\ Program Studi Manajemen, Sekolah Tinggi Ilmu Ekonomi Tri Dharma Nusantara \\ Jalan Kumala 2 No.51 \\ Sumarsih \\ Email: sumarsihrasyid@gmail.com \\ Program Studi Manajemen, Fakultas Ekonomi, Universitas Sulawesi Barat \\ Jalan Prof. Baharuddin Lopa S. Talumung Majene Sulbar
}

\begin{abstract}
ABSTRAK
Tujuan riset ini adalah untuk mengetahui pengaruh pembelajaran daring dan motivasi belajar terhadap hasil belajar mahasiswa pada masa pandemi Covid-19. Penelitian ini menggunakan pendekatan kuantitatif dengan metode survei menggunakan skala Likert dengan melakukan penyebaran kuesioner yang dibuat dalam bentuk google form. Teknik pengambilan sampel menggunakan random sampling yaitu mahasiswa yang mengambil mata kuliah kompetensi semester VI program studi manajemen yang berjumlah 75 mahasiswa. Teknik analisis data menggunakan pendekatan Partial Least Square (PLS). Hasil riset menunjukkan bahwa pembelajaran daring dan motivasi belajar berpengaruh positif dan signifikan terhadap hasil belajar mahasiswa.
\end{abstract}

Kata Kunci: Pembelajaran daring; motivasi belajar; hasil belajar mahasiswa

\section{ABSTRACT}

The purpose of this research is to determine the effect of online learning and learning motivation on student learning outcomes during the Covid-19 pandemic. This study uses a quantitative approach with a survey method using a Likert scale by distributing questionnaires made in the form of google form. The sampling technique used was random sampling, namely students who took the competence course in semester VI of the management study program, totaling 75 students. The data analysis technique used the Partial Least Square (PLS) approach. The results of the research show that online learning and learning motivation have a positive and significant effect on student learning outcomes.

Keywords: Online learning; learning motivation; learning outcomes 


\section{PENDAHULUAN}

Pendidikan berperan penting dalam kehidupan masyarakat karena merupakan sarana untuk mengembangkan dan meningkatkan kualitas dan kapasitas sumber daya manusia. Dalam mewujudkan pendidikan yang baik bagi seluruh lapisan masyarakat, maka dunia pendidikan harus didukung oleh sumber daya manusia yang berkualitas dan berkompeten (Mukhtar \& MD, 2020). Salah satu cara untuk meningkatkan mutu pendidikan agar tidak menimbulkan kesenjangan antara pendidikan dan teknologi yaitu dengan mengikuti perkembangan kemajuan teknologi. Memanfaatkan teknologi yang ada merupakan salaha satu cara proses pembelajaran dalam dunia pendidikan (Aurora \& Effendi, 2019). Adanya tantangan di abad 21 yang penuh kompleksitas, dunia pendidikan harus mendapat respon positif dan adaptif dengan mengikuti perkembangan teknologi (Gamar et al., 2018). Penggunaan teknologi dalam dunia pendidikan telah menjadi isu yang sangat penting dalam berbagai kegiatan (Orgaz et al., 2018; Traxler, 2018), perkembangan teknologi revolusi industri 4.0 saat ini telah mengubah gaya hidup masyarakat, setiap individu harus mengetahui bagaimana cara memanfaatkan teknologi yang ada untuk mempermudah kehidupan setiap orang (Saricoban et al, 2019), teknologi dapat mendorong inovasi dalam penciptaan sistem pendidikan baik di dalam maupun di luar kelas untuk memungkinkan munculnya proses pembelajaran jarak jauh (Almeida \& Simoes, 2019).

Pendidikan yang menggunakan unsur teknologi informasi dalam pembelajaran online merupakan sebuah inovasi dalam dunia pendidikan. Menurut (Mustofa et al., 2019) bahwa elearning adalah sistem yang diterapkan dalam pendidikan jarak jauh dengan menggunakan metode pengajaran yang berbeda yang diterapkan melalui Internet dan Web 2.0 (Brolpito, 2018), artinya bahwa dengan adanya teknologi sebagai sarana dan jaringan internet sebagai sistem dalam proses pembelajaran online. Beberapa penelitian menjelaskan bahwa dalam konteks perguruan tinggi telah banyak yang melakukan pembelajaran secara online (Crews \& Parker, 2017; Mather \& Sarkans, 2018), pembelajaran secara daring membantu dalam menyediakan akses belajar yang memberikan manfaat bagi semua orang sehingga proses pembelajaran dalam ruang lingkup kelas tidak menjadi hambatan dan dinilai efektif terutama di perguruan tinggi (Ahmed, 2018), namun menurut (Pilkington, 2018) bahwa tidak semua pembelajaran dapat dilakukan ke dalam lingkungan pembelajaran secara daring. Pembelajaran daring dapat disebut sebagai media pembelajaran karena menggunakan internet yang bertujuan untuk memberikan solusi dan meningkatkan pengetahuan dan keterampilan seseorang (Sabran \& Sabara, 2019) saat ini perkuliahan daring di lembaga pendidikan yang 
paling banyak digunakan adalah menggunakan aplikasi Zoom Cloud Meeting.

Selama masa pandemi COVID-19, proses perkuliahan yang dilaksanakan di STIE Tri Dharma Nusantara berlangsung secara daring. Hal ini sudah menjadi kebiasaan baru bagi dosen dan mahasiswa saat melakukan perkuliahan, dengan tujuan untuk melanjutkan proses komunikasi dan informasi dosen dan mahasiswa, baik informasi yang terkait materi perkuliahan maupun informasi pribadi (Ferazona \& Suryanti, 2020). Melalui pembelajaran daring, mahasiswa dapat mengakses materi perkuliahan dari aplikasi yang telah disediakan oleh dosen (Meiza et al., 2020). Dengan pembelajaran daring, pengajar juga harus lebih kreatif lagi dalam menyampaikan materi dalam proses pembelajaran dengan membuat video berupa tutorial yang diunggah ke YouTube dan memanfaatkan Google Classroom, Google Forms, Whats App Group, dan aplikasi video conference seperti Zoom

Permasalahan yang dihadapi mahasiswa dalam pembelajaran daring adalah biaya pengeluaran pulsa internet yang meningkat dari sebelumnya, menghadapi materi yang tidak mereka pahami, dan komunikasi satu arah berlangsung selama fase pembelajaran daring. Hal ini didukung oleh penelitian (Naserly, 2020) bahwa respon komunikasi yang lambat melalui aplikasi WhatsApp, menggunakan aplikasi Zoom menguras kuota internet, begitupun juga materi yang diberikan kurang dipahami dengan menggunakan aplikasi Google Classroom. Pendidik juga merasakan hal yang sama dalam hal ini adalah dosen, mereka tidak mengetahui tingkat pengetahuan mahasiswa secara langsung pada saat materi disampaikan. Pembelajaran yang dilakukan oleh dosen sangat besar pengaruhnya terhadap keberhasilan mahasiswa dalam memahami materi pelajaran. Oleh karena itu, sebagai dosen harus berusaha semaksimal mungkin untuk memberikan materi meskipun dalam kondisi pembelajaran menggunakan sistem daring dan memastikan bahwa mahasiswa yang terlibat dalam pembelajaran memahami materi yang disampaikan.

Penelitian (Prasetya \& Harjanto, 2020) menunjukkan bahwa pembelajaran secara daring melalui relevansi pembelajaran, daya tarik e-learning, efektivitas, efisiensi dan produktivitas pembelajaran berpengaruh signifikan terhadap hasil belajar mahasiswa. Senada penelitian (Liu \& Ilyas, 2020), bahwa pembelajaran secara online berbasis Zoom Cloud Meeting memiliki dampak yang signifikan terhadap hasil belajar mahasiswa. Namun berbeda dengan penelitian (Dwi et al., 2020) yang mengatakan bahwa pembelajaran daring kurang efektif di masa pandemi karena kurangnya sarana dan prasarana serta kurangnya persiapan untuk pendidikan teknologi. Penelitian (Rahardja et al., 2019) bahwa kurangnya motivasi belajar yang dimiliki oleh mahasiswa dapat berpengaruh terhadap pembelajaran online sehingga hasil 
belajar tidak optimal. Tolak ukur dalam keberhasilan pembelajaran mahasiswa adalah hasil belajar dari nilai mahasiswa (Dhewy, 2020). Hasil belajar dapat dicapai ketika mahasiswa sudah memahami pembelajaran yang disertai dengan perubahan kognitif, afektif, dan keterampilan. Hasil belajar merupakan kemampuan mahasiswa yang didapatkan melalui proses evaluasi penilaian yang dirancang untuk mengukur hasil belajar dari mata kuliah (Supriadi, 2019). Adapun faktor-faktor yang dapat mempengaruhi hasil belajar yaitu faktor internal dan faktor eksternal. Faktor internal yaitu; kesehatan, intelegensi dan bakat, minat dan motivasi, dan cara belajar. Sedangkan faktor eksternal yaitu; keluarga, sekolah/kampus, masyarakat, dan lingkungan (Slameto, 2010)

Faktor internal yang mempengaruhi hasil belajar salah satunya adalah motivasi. Motivasi adalah dorongan dan semangat yang dimiliki oleh mahasiswa dalam mencapai suatu prestasi. Ketika motivasi belajar yang dimiliki rendah maka akan berdampak pula terhadap hasil belajar yang rendah. Menurut teori Behaviorisme, adanya motivasi berperan penting untuk mendorong mahasiswa menampilkan sikap atau perilaku hasil belajar yang diharapkan. Motivasi mahasiswa muncul dari sugesti dan penguatan yang diberikan, serta dari keinginan mahasiswa itu sendiri untuk dapat memahami sesuatu atau mencapai hasil belajar yang diharapkan. Motivasi belajar memiliki indikator yaitu keinginan untuk sukses, memiliki kebutuhan untuk belajar, memiliki tujuan dan harapan, apresiasi dalam belajar, yang kelima adalah kegiatan yang menarik, dan yang keenam adalah lingkungan belajar kondusif (Uno, 2019).

Penelitian (Islamiyah, 2019) menunjukkan bahwa motivasi berpengaruh positif dan signifikan terhadap hasil belajar, adanya motivasi merupakan alat untuk mencapai suatu tujuan. Senadap penelitian (Efriza et al., 2020) bahwa terdapat pengaruh positif dan signifikan antara motivasi belajar terhadap hasil belajar, hal ini disebabkan karena motivasi merupakan cara untuk meningkatkan hasil belajar mahasiswa. Adanya motivasi dapat membuat mahasiswa lebih fokus dan konsentrasi dalam belajar. Namun berbeda dengan penelitian penelitian (Gunawan dkk, 2018), bahwa motivasi tidak memiliki pengaruh yang signifikan terhadap hasil belajar. Senada penelitian (Wijaya \& Bukhori, 2017) bahwa motivasi belajar tidak signifikan terhadap hasil belajar siswa, artinya bahwa motivasi saja tidak cukup dalam meningkatkan hasil belajar mahasiswa tanpa adanya usaha.

Berdasarkan fenomena dan hasil penelitian sebelumnya, diketahui masih terdapat research gap sehingga peneliti tertarik untuk mengkaji terkait motivasi belajar terhadap hasil belajar mahasiswa secara heuristik pada pembelajaran daring pada masa pandemi Covid-19. 
Riset ini bertujuan untuk mengetahui apakah pembelajaran daring dan motivasi belajar berpengaruh terhadap hasil belajar mahasiswa di Kampus STIE Tri Dharma Nusantara Makassar.

\section{METODE PENELITIAN}

Riset ini menggunakan pendekatan kuantitatif dengan melakukan studi kausal untuk menguji hubungan antara pembelajaran daring dan motivasi belajar terhadap hasil belajar mahasiswa. Responden dalam penelitian ini adalah mahasiswa yang mengambil mata kuliah Kompetensi pada Semester VI Program Studi Manajemen STIE Tri Dharma Nusantara yang berjumlah 75 mahasiswa. Pengumpulan data dilakukan dengan survey melalui menyebarkan kuesioner menggunakan Google form dengan skala Likert. Pengambilan sampel menggunakan teknik simple random sampling, dimana setiap elemen yang membentuk populasi mempunyai peluang yang sama untuk dipilih sebagai sampel (Sugiyono, 2017). Adapun teknik analisis data penelitian ini menggunakan pendekatan Partial Least Squares (PLS).

\section{HASIL DAN PEMBAHASAN}

\section{Outer Model}

Untuk uji validitas konvergensi, nilai dari average variance extracted (AVE) lebih besar dari 0,50. Adapun hasil uji average variance extracted (AVE) dapat dilihat tabel dibawah ini:

Tabel 1. Hasil Uji Validitas

\begin{tabular}{cl}
\hline Variabel & AVE \\
\hline Pembelajaran Daring $(\mathrm{X} 1)$ & 0,833 \\
\hline Motivasi Belajar $(\mathrm{X} 2)$ & 0,869 \\
\hline Hasil Belajar Mahasiswa $(\mathrm{Y})$ & 0,752 \\
\hline
\end{tabular}

Tabel 1 menunjukkan bahwa nilai masing-masing skor AVE lebih besar dari 0,50 sehingga menerima uji validitas konvergensi. Ini berarti bahwa variabel manifes di setiap konstruk berkorelasi kuat. Penelitian ini juga mengkaji bagaimana validitas diskriminatif dilihat sebagai fungsi dari nilai factor loading dengan nilai lebih besar dari 0,70, dan menunjukkan bahwa keberadaan konfigurasi memiliki nilai validitas diskriminan yang kuat. Nilai factor loading untuk semua konstruk menunjukkan bahwa nilai korelasi untuk setiap indikator lebih besar daripada korelasi indikator lainnya, sehingga validitas uji instrumen 
dapat diterima.

Nilai composite reliability digunakan untuk mengukur hasil uji reliabilitas, dapat dilihat pada tabel dibawah ini:

Tabel 2. Hasil Uji Reliabilitas

\begin{tabular}{ccc}
\hline Variabel & Composite Reliability & Cronbach's Alpha \\
\hline Pembelajaran Daring (X1) & 0,961 & 0,949 \\
\hline Motivasi Belajar (X2) & 0,975 & 0,970 \\
\hline Hasil Belajar Mahasiswa (Y) & 0,948 & 0,934 \\
\hline
\end{tabular}

Tabel 2 menunjukkan bahwa indikator setiap konstruk > 0,70 sehingga hasil uji composite reliability terpenuhi dan instrumen bisa dikatakan reliabel.

\section{Inner Model}

Pengujian model struktural (Inner Model) dilakuakan apabila model yang diestimasi memenuhi kriteria dari outer model. Untuk menilai pengaruh variabel independen apakah memiliki pengaruh terhadap variabel dependen maka menggunakan uji R-Square. Adapun nilai $R$-Square dilihat pada tabel di berikut ini:

Tabel 3. Hasil Uji R-Square

\begin{tabular}{cc}
\hline Variabel & R-Square \\
\hline Hasil Belajar Mahasiswa $(\mathrm{Y})$ & 0,554 \\
\hline
\end{tabular}

Tabel 3 menunjukkan bahwa nilai $R$-Square pada konstruk hasil belajar mahasiswa sebesar 0,554 artinya bahwa variabel hasil belajar mahasiswa yang dipengaruhi oleh variabel pembelajaran daring dan motivasi belajar sebesar 55,4\%, sedangkan 44,6\% dipengaruhi variabel lain.

\section{Pengujian Hipotesis}

Pengujian hipotesis diterima atau ditolak dilakukan analisis dengan cara membandingkan nilai t-hitung dengant-tabel. Jika t-hitung > t-tabel maka hipotesis diterima. Adapun hasil uji hipotesis pada tabel berikut:

Tabel 4 . Uji Hipotesis

\begin{tabular}{lcccc}
\hline $\begin{array}{c}\text { Hubungan antar } \\
\text { Variabel }\end{array}$ & $\begin{array}{c}\text { Original } \\
\text { Sample (O) }\end{array}$ & $\begin{array}{c}\text { Standard } \\
\text { Deviation } \\
\text { (STDEV) }\end{array}$ & $\begin{array}{c}\text { T Statistics } \\
(\mid \text { O/STERR } \mid)\end{array}$ & P Value \\
\hline Pembelajaran Daring & 0,539 & 0,101 & 5,866 & 0,000 \\
\hline
\end{tabular}




\begin{tabular}{|c|c|c|c|c|}
\hline $\begin{array}{l}\text { (X1) -> Hasil Belajar } \\
\text { Mahasiswa (Y) }\end{array}$ & & & & \\
\hline $\begin{array}{l}\text { Motivasi Belajar } \\
(\mathrm{X} 2) \text {-> Hasil Belajar } \\
\text { Mahasiswa (Y) }\end{array}$ & 0,211 & 0,091 & 2,326 & 0,020 \\
\hline
\end{tabular}

\section{Pengaruh Pembelajaran daring terhadap Hasil Belajar Mahasiswa}

Berdasarkan hasil riset menunjukkan bahwa nilai t-statistik 5,866 > t-tabel 1,96 dengan nilai P-value $0,000<0,05$ sedangkan nilai dari original sample adalah positif, sebesar 0,539 yang menunjukkan hubungan positif antara pembelajaran daring dengan hasil belajar mahasiswa, sehingga hasil penelitian menunjukkan adanya pengaruh signifikan antara pembelajaran daring terhadap hasil belajar mahasiswa. Senada penelitian (Liu \& Ilyas, 2020) bahwa pembelajaran daring merupakan salah satu sarana alternatif media pembelajaran daring selama belajar di rumah sehingga hasil risetnya menyatakan bahwa dengan pembelajaran daring dengan aplikasi Zoom Cloud Meeting berpengaruh signifikan terhadap hasil belajar mahasiswa. Begitupun penelitian (Prasetya \& Harjanto, 2020) bahwa mutu pembelajaran daring yang berdasarkan lima faktor yaitu relevansi, daya tarik, efektifitas dan efisiensi, serta produktifitas menunjukkan bahwa mutu pembelajaran daring media pembelajaran di kejuruan sudah baik, sehingga mutu pembelajaran daring memiliki pengaruh positif terhadap hasil belajar mahasiswa.

\section{Pengaruh Motivasi Belajar terhadap Hasil Belajar Mahasiswa}

Berdasarkan hasil riset menunjukkan bahwa nilai t-statistik 2,326 > t-tabel 1,96 dengan nilai P-value $0,020<0,05$, sedangkan nilai original sample adalah positif sebesar 0,211 artinya bahwa ada hubungan positif antara motivasi belajar dengan hasil belajar mahasiswa. Sejalan dengan penelitian (Supriadi, 2019) bahwa motivasi belajar memiliki pengaruh signifikan terhadap hasil belajar mahasiswa. Adanya motivasi belajar yang tinggi akan mempengaruhi hasil belajar yang di diperoleh dari mahasiswa. Senada dengan penelitian (Firnando, 2020) menyatakan bahwa motivasi belajar berpengaruh positif dan signifikan terhadap hasil belajar mahasiswa. Untuk memperoleh hasil belajar yang tinggi, maka mahasiswa juga perlu memiliki motivasi belajar yang tinggi, artinya dengan adanya motivasi maka hasil yang dicapai juga lebih baik. Hasil belajar dapat berupa perubahan sikap, nilai dan pemahaman suatu pelajaran, kehadiran, kedisiplinan, dan lainnya yang bersifat positif. 


\section{KESIMPULAN DAN SARAN}

Berdasarkan hasil analisis bahwa metode pembelajaran daring memiliki pengaruh positif dan signifikan terhadap hasil belajar mahasiswa. Demikian pula motivasi belajar berpengaruh positif dan signifikan terhadap hasil belajar mahasiswa. Berbagai kekurangan ditemukan dalam proses pembelajaran daring ditengah pandemi Covid-19, bukan menjadi alasan dan kendala bagi mahasiswa untuk mencapai hasil belajar yang baik, namun tetap mengoptimalkan sistem pembelajaran daring karena dimasa pandemi seperti ini hanya teknologi sebagai sarana dalam mentransfer ilmu dari dosen ke mahasiswa

Diharapkan hasil riset ini dapat digunakan sebagai bahan evaluasi dan masukan dari berbagai pihak dalam melakukan pembelajaran daring di perguruan tinggi, penelitian ini juga diharapkan menjadi bahan kajian bagi peneliti selanjutnya dalam menganalisis dan mengembangkan motivasi belajar mahasiswa dalam pembelajaran daring dimasa yang akan datang dan menambahkan variabel lain yang belum dikaji dalam penelitian ini. Dalam melakukan pembelajaran daring baik dosen maupun mahasiswa harus mempersiapkan pembelajaran sehingga dapat menghasilkan hasil belajar yang diharapkan. Persiapan yang harus dilakukan dosen dan mahasiswa terkait dengan hubungan pedagogik antara dosen dan mahasiswa serta ketersediaan fasilitas pembelajaran seperti media pembelajaran, materi, penggunaan aplikasi, dan akses jaringan. Diharapkan juga dapat memberikan pemahaman kepada seluruh dosen dalam memberikan pelajaran, dan memberikan motivasi kepada mahasiswa pada awal dan akhir pembelajaran agar mereka semangat dan menyukai dalam melaksanakan proses belajar mengajar.

\section{DAFTAR PUSTAKA}

Ahmed, R. 2018. Effects of online education on encoding and decoding process of students and teachers. MCCSIS 2018 - Multi Conference on Computer Science and Information Systems; Proceedings of the International Conferences on e-Learning 2018, 2018-July, $42-48$.

Almeida, F., \& Simoes, J. 2019. The role of serious games, gamification and industry 4.0 tools in the education 4.0 paradigm. Contemporary Educational Technology, 10(2), 120 136.

Aurora, A., \& Effendi, H. 2019. Jtev (Jurnal Teknik Elektro Dan Vokasional) Pengaruh Penggunaan Media Pembelajaran E-Learning Terhadap Motivasi Belajar Mahasiswa Di Universitas Negeri Padang. Universitas Negeri Padang. JTEV, 5(2), 11-16.

Brolpito, A. 2018. Digital Skills and Competence, and Digital and Online Learning. European Training Foundation. 
Dhewy, R. 2020. Pengaruh Pembelajaran Berbasis Daring Terhadap Hasil Belajar Statistika Pada Mahasiswa Stikes Anwar Medika Sidoarjo. Open Journal Systems, 14(11), 35553558.

Crews, J., \& Parker, J. 2017. The Cambodian experience: Exploring university students' perspectives for online learning. Issues in Educational Research, 27(4), 697-719.

Dwi, B., Amelia, A., Hasanah, U., \& Putra, A. M. 2020. Analisis Keefektifan Pembelajaran Online di Masa Pandemi Covid-19. Jurnal Pendidikan Guru Sekolah Dasar, 2(1), 3.

Efriza, R., Caska, C., \& Makhdalena, M. 2020. Analysis of Factors Affecting Student Learning Achievement of Social Sciences Subjects in Muhammadiyah Middle School Rokan Hulu Regency. Journal of Educational Sciences, 4(3), 529.

Ferazona, S. S., \& Suryanti. 2020. Pengaruh Pembelajaran Daring Terhadap Hasil Belajar Kognitif Mahasiswa Pada Mata Kuliah Limnologi. Journal of Research and Education Chemistry, 2(2), 102.

Firnando, D. 2020. Pengaruh motivasi belajar terhadap hasil belajar mahasiswa fakultas hukum universitas Saburai. Nusantara: Jurnal Ilmu Pengetahuan Sosial, 7(2), 408-420.

Gamar, M. M., Al Faruq, M. S., \& Lina, L. 2018. Challenging the Indonesian Primary Education in Industrial Revolution 4.0 Era. 269(CoEMA), 46-48.

Gunawan; Kustiani; Hariani. 2018. Faktor-Faktor Yang Mempengaruhi Hasil Belajar. Journal of Education, 12(1), 76-77.

Hussin, A. 2018. Education 4.0 Made Simple: Ideas For Teaching. International Journal of Education and Literacy Studies, 6(3), 92-98.

Islamiyah, N. 2019. Pengaruh Fasilitas Belajar dan Motivasi Belajar Terhadap Prestasi Belajar Mahasiswa Jurusan Pendidikan Ekonomi 2017 Universitas Negeri Surabaya. JPEKA: Jurnal Pendidikan Ekonomi, Manajemen Dan Keuangan, 3(1), 23.

Liu, A. N. A. M., \& Ilyas, I. 2020. Pengaruh Pembelajaran Online Berbasis Zoom Cloud Meeting Terhadap Hasil Belajar Mahasiswa Fisika Universitas Flores. Jurnal Pendidikan Fisika Dan Keilmuan (JPFK), 6(1), 34.

Mather, M., \& Sarkans, A. 2018. Student Perceptions of Online and Face-to-Face Learning conditions of the Creative Commons Attribution license (CC BY-NC-ND). International Journal of Curriculum and Instruction, 10(2), 61-76.

Meiza, A., Hanifah, F. S., Natanael, Y., \& Nurdin, F. S. 2020. Analisis Regresi Ordinal untuk melihat Pengaruh Media Pembelajaran Daring terhadap Antusiasme Mahasiswa Era Pandemi Covid. Digital Library UIN Sunan Gunung Jati, 8.

Mukhtar, A., \& MD, L. 2020. Pengaruh Kompetensi Guru Terhadap Kinerja Guru Dan Prestasi Belajar Siswa Di Kota Makassar. Idaarah: Jurnal Manajemen Pendidikan, 4(1), 1.

Mustofa, M. I., Chodzirin, M., Sayekti, L., \& Fauzan, R. 2019. Formulasi Model Perkuliahan Daring Sebagai Upaya Menekan Disparitas Kualitas Perguruan Tinggi. Walisongo Journal of Information Technology, 1(2), 151.

Naserly, M. K. 2020. Implementasi Zoom, Google Classroom, Dan Whatsapp Group Dalam 
Mendukung Pembelajaran Daring (Online) Pada Mata Kuliah Bahasa Inggris Lanjut. Journal of Chemical Information and Modeling, 4(2), 155-165.

Orgaz, F., Moral, S., \& Domínguez, C. 2018. Student's Attitude and Perception with the Use of Technology in the University. Journal of Educational Psychology - Propositos $y$ Representaciones, 6(2), 277-299.

Pilkington, O. A. 2018. Active learning for an online composition classroom: Blogging as an enhancement of online curriculum. Journal of Educational Technology Systems, 47(2), 213-226.

Prasetya, T. A., \& Harjanto, C. T. 2020. Pengaruh Mutu Pembelajaran Online Dan Tingkat Kepuasan Mahasiswa Terhadap Hasil Belajar Saat Pandemi. Jurnal Pendidikan Teknologi Dan Kejuruan, 17(2), 188-197.

Rahardja, U., Lutfiani, N., Handayani, I., \& Suryaman, F. M. (2019). Motivasi Belajar Mahasiswa Terhadap Metode Pembelajaran Online iLearning + Pada Perguruan Tinggi. Jurnal Ilmiah SISFOTENIKA, 9(2), 192-202.

Sabran, \& Sabara, E. 2019. Keefektifan Google Classroom sebagai media pembelajaran. PROSIDING SEMINAR NASIONAL LEMBAGA PENELITIAN UNIVERSITAS NEGERI Makasar, 122-125.

Sarıcoban, Arif;İ Tosuncuoğlu, Rfan; Kırmızı, Ö. 2019. A technological pedagogical content knowledge (TPACK) assessment of pre-service EFL teachers learning to teach English as a foreign language (pp. 1122-1138).

Slameto. 2010. Belajar \& Faktor-Faktor Yang Mempengaruhi. Jakarta: Rineka Cipta.

Sugiyono. 2017. Metode Penelitian Kuantitatif, Kualitatif, dan R\&D. Bandung : Alfabeta, CV

Supriadi, D. 2019. Pengaruh Motivasi Belajar Terhadap Hasil Belajar Matakuliah Metode Penelitian Mahasiswa Semester Genap Tahun 2018/2019. 4(2 Juli), 97-105.

Traxler, J. 2018. Distance learning-Predictions and possibilities. Education Sciences, 8(1).

Uno, H. B. 2016. Teori Motivasi \& Pengukurannya Analisis di Bidang Pendidikan. Bumi Aksara

Wijaya, O. P., \& Bukhori, I. 2017. Effect of Learning Motivation, Family Factor, School Factor, and Community Factor on Student Learning Outcomes on Productive Subjects. Jurnal Pendidikan Bisnis Dan Manajemen, 3(3), 192-202. 